MATHEdunesa

Jurnal IImiah Pendidikan Matematika Volume 9 No. 2 Tahun 2020

ISSN :2301-9085

\title{
STUDENTS' STRATEGIC COMPETENCE PROFILES IN SOLVING MATHEMATICS PROBLEM BASED ON LEARNING STYLES
}

\author{
Siti Utari Widyanti \\ Mathematics Education, Faculty of Mathematics and Science, Universitas Negeri Surabaya \\ Email: sitiwidyanti16030174089@mhs.unesa.ac.id \\ Siti Khabibah \\ Mathematics Education, Faculty of Mathematics and Science, Universitas Negeri Surabaya \\ Email: sitikhabibah@unesa.ac.id
}

\begin{abstract}
The purpose of this research was to describe the profiles of students' strategic competences that have visual, auditory, and kinesthetic learning style in solving mathematics problem. There were three subjects, one visual student, one auditory student, one kinesthetic student, which were chosen from the eleventh grade students of Science with high mathematical abilities, good communication skills, and the same gender. The instruments used were the VAK learning style test, the mathematics ability test, the mathematics problem solving test, and the interview guidelines. The results obtained the description of visual student profile, auditory student profile, and kinesthetic student profile in selecting and implementing strategies when formulating, representing, and solving problems, as follows: (1) visual student read silently, imagined, and drew to understand the problem; mentioned the known and unknown information verbally with the help of images; used images and symbols to represent problems; observed, analyzed and broke down images to find relevant concepts and formulas; solved the problem using those concepts and formulas. (2) Auditory student read in a low voice and drew to understand the problem; mentioned the known and unknown information verbally and in writing; used images and symbols to represent problems; observed images and recalled her knowledge to find relevant concepts and formulas; solved the problem using those concepts and formulas. (3) Kinesthetic student read silently while drawing to understand the problem; mentioned the known and unknown information verbally followed by her body cues; used images and symbols to represent problems; observed, analyzed and broke down images to find relevant concepts and formulas; solved problems using those concepts and formulas; random checked to examine her solution. The results of this study are important as information for mathematics teachers about the strategic competences of visual, auditory, and kinesthetic students in solving mathematics problems. From this information, mathematics teachers are expected to be able to design learning that can facilitate all students in developing their strategic competences.

Keywords: strategic competence, visual learning style, auditory learning style, kinesthetic learning style
\end{abstract}

\section{INTRODUCTION}

Mathematics is result of human thought about objects around them and used to solve problems that occur in life (Manullang et al., 2017). Therefore, it is important to study mathematics because this science can be applied to solve problems in real life. There are several competencies that need to be achieved by students in learning mathematics at the Secondary Education level (X-XII class), which are mentioned in the copy of Permendikbud Attachment number 21 of 2016 concerning the standards of primary and secondary education, namely (1) showing a logical, critical, creative, analytical, careful, thorough, responsible, responsive, and not easily give up in solving problems; (2) have a curiosity, confidence, enthusiasm for continuous learning, reflective thinking, and an interest in mathematics, also have a sense of trust in the power and usefulness of mathematics. These mean that mathematics and mathematics problem solving are important to be taught to students.

According to Kilpatrick et al. (2001), there are five interrelated components that need to be developed in students so that they can succeed in learning mathematics. One of those is strategic competence. Strategic competence is a mental activity in selecting and implementing appropriate strategies to formulate, represent, and solve mathematics problem.

Based on the 2019 national exam results report (Puspendik Kemendikbud, 2019) and research which conducted by Wasida and Hartono (2018), high school students of science department were having trouble with geometry and trigonometry. Further explained, in Wasida and Hartono (2018), that students' difficulties in working on national exam questions were on understanding questions which included determining what was known and asked, determining formulas, determining systematic solution, solving basic mathematics operations, 
determining the relationship between facts and concepts, and determining the final answer. These indicate that students have difficulty when exploring their strategies in dealing with mathematics problems.

Strategic competence can be developed through problem solving activities (Suh, 2007; Samuelsson, 2010) because, according to Syukriani (2018), problem solving requires critical, creative thinking, and applying certain strategies to understand the situations and find the solutions of problems. This shows that strategic competence has a close relationship with problem solving. Students' strategic competence can be seen when students explore their strategies for formulating, representing, and solving problems. The strategy can be either the easiest way also effective for students and the concepts used in solving problems.

Each individual must has their own uniqueness that distinguishes individuals from one another. Likewise in the case of learning, each student has their own way that is considered easy to absorb, organize, and process the information received. This is called learning style (Bire et al., 2014). Deporter and Hernacki (2004) divided learning style into three types, namely visual, auditory, and kinesthetic. Visual students are students who will receive information effectively by seeing and looking, such as seeing and looking pictures, illustrations, charts, diagrams, maps, videos, and demonstrations. Auditory students are students who will receive information effectively by hearing and listening, such as hearing and listening to sound or information either through the intermediaries of people or other audio devices. Kinesthetic students are students who will receive information effectively by touching and doing, such as working directly or relating to experience and practice, both real and simulated. Actually, many individuals combine these three learning styles, but there are also many individuals who are more inclined to one of the three learning styles. Strategic competence has a relationship with students' learning styles because in solving problems involved information processing activities and each individual has a tendency to process information. Thus, each type of students' learning style (visual, auditory, kinesthetic) will influence the strategies used in solving problems (Syukriani, 2018; Hartati, 2012; Kilpatrick et al., 2001).

Based on explanation above, it is important to study about the profiles of visual, audiory, and kinesthetic student's strategic competence in solving mathematics problem. Some researchers have conducted research on students' strategic competence in solving mathematics problem, some of them are (1) research conducted by Syukriani (2016) which aimed to describe the strategic competence of high school students with high mathematics abilities in solving mathematics problem. The result was students with high mathematics abilities tended to use images for analyzing the problem situation, so students understood easily the problem situation and were able to produce appropriate forms of image representation. It made easier for students to use the proper symbol representation. The symbol representation used were formulas that are appropriate to solve the problem. That study has relevance with this research, that is equally study about strategic competence of high school students. (2) Research conducted by Pierce (2019) which aimed to investigate the role of gender and learning modalities, how students process information in solving mathematics problems. Some of the relevant results were the students' approach of solving mathematics problems appeared on the students' actions or behaviors that can be observed, but not on paper, such as (1) visual students often saw images in their minds during the process of problem solving, (2) Auditory students often spoke both to themselves and to researchers during the process of problem solving, (3) kinesthetic students moved a lot or involved a lot of physical movements during problem solving. That study has relevance with this research, that is equally study about the mathematics problem solving of visual, auditory, and kinesthetic students. The difference between the two studies with this research is this research aims to describe the profiles of visual, auditory, and kinesthetic high school students' strategic competence in solving mathematics problem. According to Montgomery and Groat (Aljaberi, 2015) understanding students learning style is important and necessary to find the best way of presenting knowledge to students. If the teacher is not able to design learning that can facilitate all students' learning styles differences, it will cause the information conveyed not received by the students properly. The students' strategic competence can be observed through the aspects and indicators below.

Table 1. The Aspects and Indicators of Students' Strategic Competence in Solving Mathematics Problem

\begin{tabular}{|c|c|c|}
\hline $\begin{array}{c}\text { Problem } \\
\text { Solving Step }\end{array}$ & $\begin{array}{c}\text { Strategic } \\
\text { Competence } \\
\text { Aspect }\end{array}$ & Indicator \\
\hline \multirow{6}{*}{ Understanding } & \multirow{4}{*}{ Formulate } & $\begin{array}{l}\text { Choosing strategy, such as } \\
\text { choosing effective way to } \\
\text { understand the problem. }\end{array}$ \\
\hline & & $\begin{array}{l}\text { Applying the chosen strategy } \\
\text { to understand the problem. }\end{array}$ \\
\hline & & $\begin{array}{l}\text { Writing or mentioning the } \\
\text { known information. }\end{array}$ \\
\hline & & $\begin{array}{l}\text { Writing or mentioning the } \\
\text { unknown information. }\end{array}$ \\
\hline & \multirow[t]{2}{*}{ Represent } & $\begin{array}{l}\text { Choosing strategy, such as } \\
\text { choosing the best data } \\
\text { representation that are } \\
\text { appropriate to the problem. }\end{array}$ \\
\hline & & $\begin{array}{l}\text { Representing the problem } \\
\text { according to the strategy } \\
\text { chosen. }\end{array}$ \\
\hline
\end{tabular}




\begin{tabular}{|c|c|c|}
\hline $\begin{array}{c}\text { Problem } \\
\text { Solving Step }\end{array}$ & $\begin{array}{c}\text { Strategic } \\
\text { Competence } \\
\text { Aspect } \\
\end{array}$ & Indicator \\
\hline \multirow{2}{*}{$\begin{array}{c}\text { Devising a } \\
\text { plan }\end{array}$} & \multirow{6}{*}{ Solve } & $\begin{array}{l}\text { Devising strategy, such as } \\
\text { selecting effective way to find } \\
\text { concepts that are relevant to the } \\
\text { problem situation. }\end{array}$ \\
\hline & & $\begin{array}{l}\text { Devising strategy, such as } \\
\text { selecting concepts that are } \\
\text { relevant to the problem } \\
\text { situation. }\end{array}$ \\
\hline \multirow{2}{*}{$\begin{array}{l}\text { Carrying out } \\
\text { the plan }\end{array}$} & & $\begin{array}{l}\text { Solving the mathematics } \\
\text { problem in accordance with the } \\
\text { selected strategies. }\end{array}$ \\
\hline & & $\begin{array}{l}\text { Solving the mathematics } \\
\text { problem in other different ways } \\
\text { or solutions. }\end{array}$ \\
\hline \multirow[t]{2}{*}{ Looking back } & & $\begin{array}{l}\text { Devising strategy,such as } \\
\text { selecting effective way to re- } \\
\text { check the problem solution } \\
\text { obtained. }\end{array}$ \\
\hline & & $\begin{array}{l}\text { Re-checking the problem } \\
\text { solution obtained in accordance } \\
\text { with the selected strategy. }\end{array}$ \\
\hline
\end{tabular}

\section{METHODS}

This research is a descriptive study with a qualitative approach that aims to describe the profiles of visual, auditory, and kinesthetic (VAK) students' strategic competence in solving mathematics problem. The subjects in this study consisted of three students selected from the eleventh grade students of Science. They are a visual student, an auditory student, and a kinesthetic student which each of them has high mathematics ability, good communication skill, and the same gender, namely women. Selecting students with high mathematics abilities because, according to Meilando et al. (2017), students with high mathematics abilities are able to solve mathematics problem well and more thoroughly than students with moderate and low mathematics abilities, so it will be easier in taking the mathematics problem solving test (TPMM) data. While selecting based on the same gender because, according to Syukriani et al. (2017), there are differences between male and female students in using strategies when solving mathematics problem.

Data collection techniques used in this study were tests and interview. The test technique uses three instruments, namely the VAK learning style test (TVAK), the mathematics ability test (TKM), and the mathematics problem solving test (TPMM). TVAK is adopted from research conducted by Ma'rifatin (2018). TKM is adapted from the National Examination (UN) questions for high school students in 2017/2018 and 2018/2019, and the National Examination (UN) for junior high school students in 2017/2018 and 2018/2019 by changing the form of multiple choice questions into a description item. The TPMM used in this study is made in the form of story and contained geometry material and is either general or unfavorable for one of the VAK learning styles. This
TPMM is consulted with a supervisor before being used. The following is the problem contained in the TPMM.

$M r$. Toni had a plot of land which was $(10 \times 5) \mathrm{m}^{2}$ and not fenced. The land was full of weeds because Mr. Toni did not plan to build anything on the land. In that land, there was a tree. That tree was $1 \mathrm{~m}$ distance from the middle of one of the land edges. Mr. Toni had a cow. One day, Mr. Toni invited his cow to the land he owned, then Mr. Toni tied his cow to a tree in the land. If the length of the rope that tied the cow was only $2 \mathrm{~m}$ length, determine the area of the land that the grass could be eaten by the cow!

The interview technique is carried out while the subjects are working on TPMM by using semi-structured interviews. It is done to observe and interview the subjects related to the subjetcs' implementation or work on TPMM. The data in this study are analyzed in accordance with the guidelines that had been made and through the process of data reduction, data presentation, and drawing conclusions.

\section{RESULTS AND DISCUSSION}

Based on TPMM and interviews data analysis, description of visual (SV), auditory (SA), and kinesthetic (SK) students' strategic competence profiles in solving mathematics problem can be presented as follows.

Visual Student's (SV) Strategic Competence Profile in Solving Mathematics Problem

\section{Formulate}

SV chose reading carefully and repeatedly to understand the mathematics problem. When SV was really faced with the mathematics problem, she read the problem carefully and silently also repeated it several times until she really understood the problem she faced. Then, SV imagined the problem situation and poured it into images. The reason SV imagined and drew was it could help her to have better understanding of the problem. This is in accordance with the statement of Gilakjani (2012) that visual students think in pictures. The following is interviews with SV when asked to explain the problem situation.

PV : If you have understood, now try to retell the problem
situation that you just read.
Mr. Toni had a land which was $(10 \times 5) \mathrm{m}^{2}$. There
was a tree in that land which was apart $1 \mathrm{~m}$ from the
middle of one of the land edges, means that the
distance was $1 \mathrm{~m}$ from one of the fences. So I first
drew the tree trunk. Then one day Mr. Toni invited
his cow to the land and tied it to a tree in the land.
The rope that tied it was $2 \mathrm{~m}$ length, means that with
the $2 \mathrm{~m}$ rope the cow could turn around and form a
circle. And in this problem, we are told to find grass
that was eaten by cow, so the area that could be
reached by the cow was equal to the area of the circle,
but reduced by the picture that was $1 \mathrm{~m}$ above it.
(while pointing to the image $)$
Then what about the size $(10 \times 5) \mathrm{m}^{2}$ ?
The shape of the land was rectangular, Miss. But I'm
P : $\quad$ rather confused about the rectangular. I just
SV


The circle is an area that can be reached by a cow, its center point is a tree, its radius is $2 m$ (a cow's rope), then the $1 \mathrm{~m}$ is the distance of the tree from the fence. This line is the fence. So what I am looking for is shaded image area. (explained while pointing to the image)

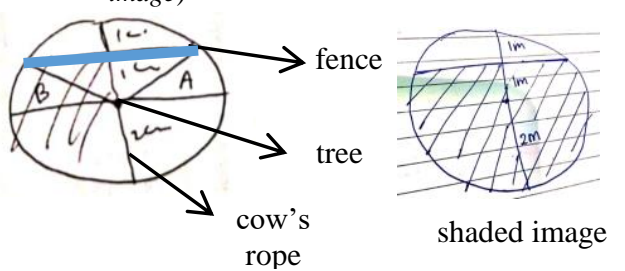

Figure 1. Representation of Overall Problem Situation Created by SV

SV explained the problem situation verbally in his own language, without looking at the text and by pointing to the image she made. This is accordance with Gunawan (2007) that visual students are very easy to imagine what they talk about, they will often see images related to information and events because it will make them easier to understand. SV understood that tree in the land was the center of the circle, $2 m$ of cow rope tied to the tree would form a circle when the cow rotated/went around maximally, the distance of the tree was $1 \mathrm{~m}$ from the middle of one of the land edges, and also she understood that the cow rope as the radius of the circle. SV also understood that Mr. Toni's land was rectangular which was $(10 \times 5) \mathrm{m}^{2}$, but SV did not understand the relationship between rectangular (Mr.Toni's land) with a circule image (area reached by cow). SV only drew the area reached by the cow and the fence that she understood without drawing the rectangular.

Based on the interview with SV, it can also be seen that SV was able to mention the known and unknown informations from the given problem.

\section{Represent}

SV chose the image and symbol representasions for the problem she faced. It can be seen through the following SV's answer sheet.

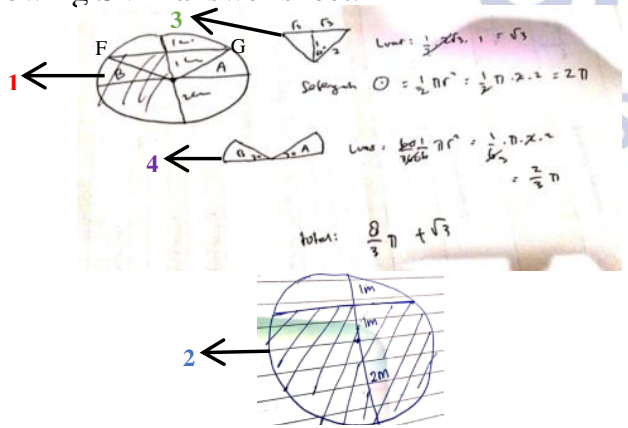

Figure 2. SV's Problem Representaion in Her Answer Sheet From Figure 2 and the interview, SV represented the problem into images, namely (1) circle with $2 m$ radius which was represented as the entire problem situation, the radius as the cow's rope, the center point as a tree in the land, and the FG line segment as a land fence; (2) a partially shaded circle image was a representation of the area reached by the cow where grass might be eaten; (3) isosceles triangle image was the result of separation from circle (1); (4) two sectors image with each angle was $30^{\circ}$ was the result of separation from circle (1). Besides SV does like presenting something into image, but another reason is because the problem presented contains geometry material, which according to Soenarjadi (2020), image representation plays an important role in solving geometry problems and will facilitate the problem solving. SV also represented the mathematics problem into symbols according to the concept she chose.

\section{Solve}

\section{Devising a Plan}

SV devised strategy in order able to determine concepts that were relevant to the mathematics problem situation she faced. The strategy was observing and analyzing images created in accordance with the problem, and then breaking it into several parts. The strategy was chosen because SV said that by breaking the image into several parts can make her easier to find formulas that are relevant to the problem situation. This is accordance with James (2009) that visual students will learn and easily absorb information by looking and seeing matters relating to images. So breaking the combined image into several parts will make SV easier to understand because the parts of the image will be presented more clearly. Then SV applied the strategy she devised to find the formulas. Firstly SV observed and analyzed circle images (1) (see Figure 2). Then broke that image into several parts of plane, namely isosceles triangle and two sectors images. From what SV did, she found formulas of isosceles triangle area, semicircle area, sector area, Pythagorean, Trigonometry (the law of sine), and addition for solving problem.

\section{Carrying Out The Plan}

SV solved the problem according to the formulas she found before, until finding the appropriate final answer. The following is SV's problem solving.

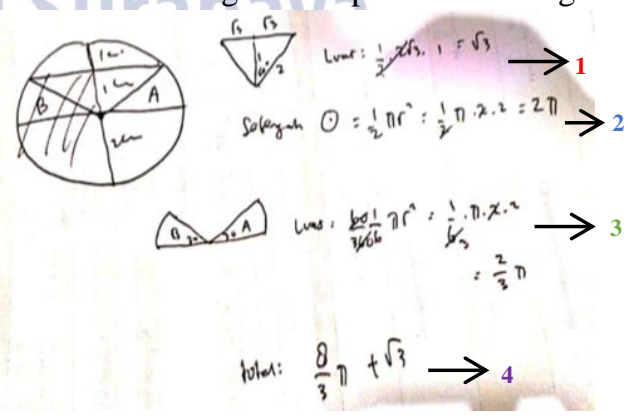

Figure 3. SV's Problem Solving

Based on Figure 3 and interviews to SV, firstly SV determined the area of isosceles triangle (1). But before that, SV determined the length of isosceles triangle base by using the Pythagorean theorem. Then SV determined 
the area of semicircle (2). After that, SV determined the area of two sectors (3), but before that SV determined the angle of those sectors. Here is SV's calculation to find the angle of sectors which is done by SV during the interview. learn and easily absorb information by hearing and listening. Therefore, SA read in low voice that would make her more focused and easier to understand the problem. Then SA drew the problem situation according to her understanding, because SA said that images she made would help her later find formulas to solve the problem. The following is interviews with SA when asked to explain the problem situation.

$\mathrm{P} \quad$ : If you have understood, now please explain me about the problem you just read.

SA : Mr. Toni had a land. The land was rectangular with $(5 \times 10) \mathrm{m}^{2}$ sized. There were many weeds in that land, Miss. Then, in the middle of the land, there was a tree which was $1 m$ distance at the land edge. $\mathrm{Mr}$. Toni tied his cow in that tree with rope which was $2 \mathrm{~m}$. What is asked by the problem is determine the area of the land which the grass could be eaten by the cow.

$\mathrm{P} \quad$ : Then from the problem you understand, what are informations can you get?

SA : From that problem, I know that Mr. Toni's land was rectangular. Then, it is known that the land was $10 \mathrm{~m}$ length and $5 \mathrm{~m}$ width. The distance between the tree to the middle of one of the land edges was $1 \mathrm{~m}$. I drew the tree in the $10 \mathrm{~m}$ length edge. Also it is known that the cow rope was $2 m$, where if the cow wastied in that tree, the cow could move around which formed of circle. But not all the circle were in the land. Hence, the area of circle that will be determined is not perfect.

P : Why did you choose to draw the tree in the $10 \mathrm{~m}$ length edge? Why not in the $5 \mathrm{~m}$ length edge? Is it possible to draw it in the $5 \mathrm{~m}$ length edge?

SA : We can also draw the tree in the $5 m$ length edge because the cow rope or radius is $2 m$, Miss. So, the diameter of the circle is $4 m$. But I'm doubt about it hehe. I chose to draw in the $10 \mathrm{~m}$ edge because I think it will be easier to solve the problem later.

\section{Looking Back}

SV realized that re-checking her answer sheet was necessary. However, SV did not re-checking her answer sheet because she was already very confused with the mathematics problem she faced.

From the explanation above, we can see that at the aspect of formulating and solving problem (devising a plan step), SV often used or involved images that were both visual image or mental image. This is accordance with Pierce (2019) that visual students often see images in their minds during the process of solving problems.

\section{Auditory Student's (SA) Strategic Competence Profile in Solving Mathematics Problem \\ 1. Formulate}

SA chose the strategy of reading repeatedly to understand the mathematics problem in the form of story. When SA was really faced with the problem, SA read the problem repeatedly until she really understood the problem and she read in a low voice. The reason SA read in a low voice was it could help her be more focused. This is accordance with the characteristics of auditory students mentioned by Deporter and Hernacki (2004) that auditory students often move their lips and read in low voice. Also in line with the opinion expressed by James (2009) that auditory students will

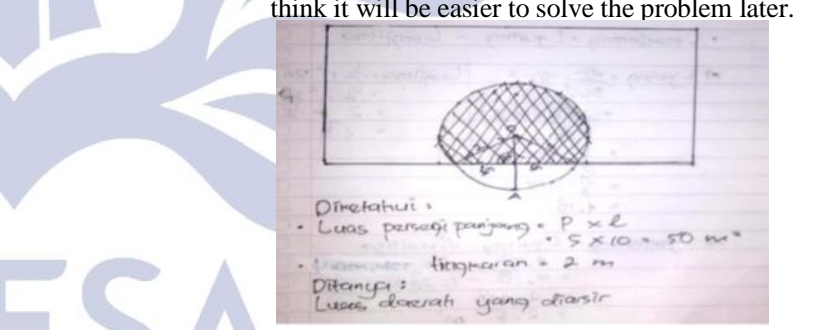

Figure 5. The Known and Unknown Informations in SA's Answer Sheet

SA explained the problem situation verbally in his own language, without seeing the text and any help. This is accordance with Gunawan (2007) that auditory students will express theirselves through sounds such as communication to theirselves or others. Therefore, SA was able to explain verbally well and without seeing the text or others help. SA understood that Mr. Toni's land was rectangular and had sized $(10 \times 5) \mathrm{m}^{2}$, namely $10 \mathrm{~m}$ length and $5 \mathrm{~m}$ width, a tree in the land was the center of circle, the distance of the tree to the middle of one of land edges was $1 \mathrm{~m}$, the cow's rope tied to the tree would form a circle if the cow moved around maximally, and she also understood that the cow's rope as the radius of the circle. SA also knew that there were several possible locations for laying tree, which could 
be in front of a side that was $10 \mathrm{~m}$ or $5 \mathrm{~m}$ in although she answered doubtfully.

Based on the interviews and Figure 5 presented above, SA was also able to mention the known and unknown information. She mentioned it verbally in her own language and without looking at the text, and also in writing that appears on her answer sheet (Figure 5).

\section{Represent}

SA chose the image and symbol representasions for the problem she faced. It can be seen through the following SA's answer sheet.

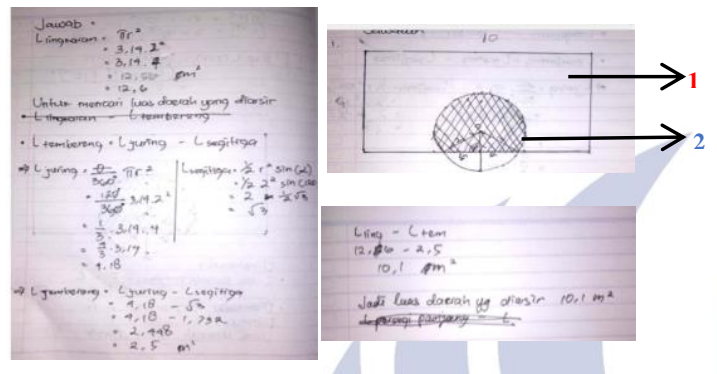

Figure 6. SA's Problem Representaion in Her Answer Sheet From Figure 6 and the interview, SA represented the problem into image that consists of (1) a rectangle as Mr. Toni's land with $10 m$ length and $5 m$ width, (2) a circle with $2 m$ radius as a form of cow movement, and the shaded area as an area that would be determined or the area of the land which the grass could be eaten by the cow. As explained before at the aspect of formulating problem, SA drew the problem situation according to her understanding, because she said that the image would help her later to find formulas to solve the problem. This is also caused by the problem presented contains geometry material, where Soenarjadi (2020) said that image representation plays an important role in solving geometry problems and will facilitate the problem solving. SA also represented the mathematics problem into symbols according to the concepts she chose.

\section{Solve}

\section{Devising a Plan}

SA devised strategy in order able to determine concepts that were relevant to the problem she faced. The strategy was observing images made in accordance with the problem, while remembering concepts that were relevant to the problem situation. That strategy was chosen because SA said that the strategy was effective in finding formulas that were relevant to the problem. Then SA applied the strategy to find the formulas. From what SA did, she found the formulas, namely circle area, sector area, scalene triangle area, and subtraction to determine the area of segment and shaded area (what is asked by the problem).

\section{Carrying Out The Plan}

SA solved the problem by using the formulas she found before until finding the appropriate final answer. The following is SA's problem solving.

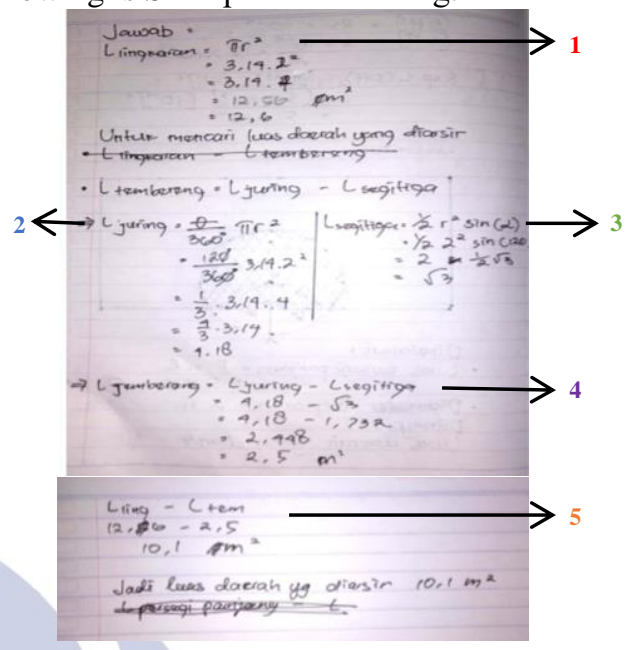

Figure 7. SA's Problem Solving

Based on Figure 7 and the interview with SA, the first step she took was calculating the area of the circle (1). Then, she decided to determine the segment area by finding the sector area subtract with the triangle area. To get the area of the sector (2), SA needed to find out the angle of sector. SA got the angle of the sector by guessing. She explained that the angle of the sector was greater than $90^{\circ}$ and less than $180^{\circ}$. Then, SA chose $120^{\circ}$ as the angle of the sector and was unable to explain mathematically how she could determine it.

After SA obtained the area of the sector, she continued to determine the area of the triangle (3). SA determined the area of the triangle by using the formula $\frac{1}{2} \times r^{2} \times \sin \alpha$, where $r$ is radius and $\alpha$ is the angle of the sector which is also the angle of the triangle. SA explained that she had used the formula when she did not know the type of the triangle and the length of the triangle base was unknown. Then, SA determined the area of the segment (4) by subtracting the area of the sector with the area of the triangle she found. Thus, SA found the area of the shaded area (5) or the area of the land that the grass could be eaten by Mr. Toni's cow by subtracting the area of the circle with the area of the segment.

Based on the interviews with SA, SA did not know whether there is other ways to solve the mathematics problem she faced.

\section{Looking Back}

SA realized that re-checking her answer sheet was necessary. However, SA did not re-check her answer sheet because she was confident with every step of her work, even though she was actually still unsure of the final solution or her calculations because she reasoned 
that in calculating process, it could happen inaccuracy that results incorrect calculation.

From the explanation above, we can see that at the aspect of formulating problem, SA often spoke by herself and was able to explain fluently. This is accordance with Pierce (2019) that during problem solving, auditory students often speak both to themselves and to researchers. Therefore, SA could explaine very well without looking at the text or others helps.

\section{Kinesthetic Student's (SK) Strategic Competence Profile in Solving Mathematics Problem \\ 1. Formulate}

SK chose the strategy of reading while pouring what she understood into images when she faced with a story problem, especially those containing geometry material. When SK was really faced with the mathematics problem, SK read silently the problem presented. This was done by SK because she was not focused when there was a commotion. SK understood the word by words from a given problem and read it repeatedly until she really understood every word presented. From every thing SK understood, her hand immediately poured it into images. This was done by SK because she would more easily understand the problem if she drew what she understood. If she only read the whole problem without being accompanied by drawing, she would have difficulty in understanding the problem. This is in accordance with the characteristics of kinesthetic students mentioned by Deporter and Hernacki (2004) that kinesthetic students are always physically oriented and move a lot. Also in line with the opinion expressed by James (2009) that kinesthetic students will learn and easily absorb information by touching and doing. Therefore, SK understood the problem accompanied by drawing which would make her easier to understand the problem. After SK had read the whole problem, she would re-check the suitability of the images she made with the problem she read. The following is interviews with SK as proof that SK really understood the given problem.

$\mathrm{P} \quad$ : Try to explain me abaout the problem you just read based on your understanding.

SK : The problem said that there was a land which was $(10 \times 5) m^{2}$. Firstly, I drew a rectangular. Then there was a tree which was $1 \mathrm{~m}$ from the middle of one of the land edges. Then I was confused, which edge of land is it actually? I thought that the length and the width of the rectangular are different sized. So I thought that is it different if I drew the tree $1 \mathrm{~m}$ apart from the length and from the width. Then I tried all possible positions. Finally, I knew the tree can be in the length or in the width. Next, the cow rope was 2 $m$ and the cow was tied in that tree. I thought that the cow tied in the tree would form a circle if it moved around. So that the images presented in my answer sheet as like this. Then what is asked by the problem is determine the area of the land that the grass could be eaten by the cow and it will form an unperfect circle.

SK was able to explain the problem situation in her own language, without seeing the text, and accompanied by gestures when explaining. This is accordance with Gunawan (2007) and Deporter and Hernacki (2001) that kinesthetic students often use gestures/body language when talking. Therefore, SK used gestures when explaining. SK understood that Mr. Toni's land was rectangular which was $(10 \times 5) \mathrm{m}^{2}$, a tree in the land as a center of circle, the distance of the tree to the middle of one of the land edges was $1 \mathrm{~m}$, the rope used to tie the cow as a radius, and the cow that moved around the land maximally would form a circle. SK also knew that there were several possible locations for tree laying, which can be placed in front of a side that is $10 \mathrm{~m}$ or $5 \mathrm{~m}$.

Based on the interview above, SK was also able to mention the known and unknown information.

\section{Represent}

SK chose the image and symbol representasions for the problem she faced. It can be seen through the following SK's answer sheet.

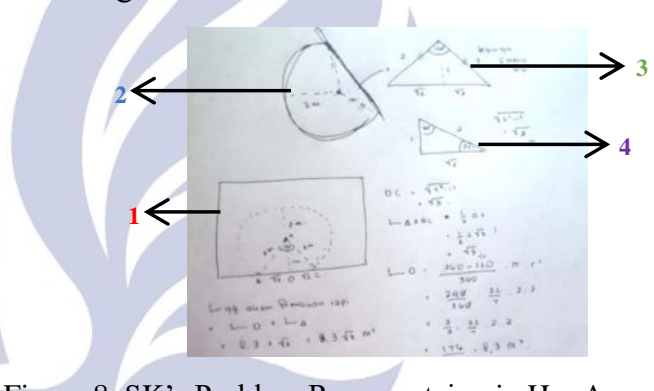

Figure 8. SK's Problem Representaion in Her Answer Sheet From Figure 8 and the interview, SK represented the problem into images, namely (1) an image that represented a whole problem situation she faced which formed a combination of some planes that consisted of a rectangular and an unperfect circle, a rectangular as Mr. Toni's land, while an unperfect circle as area that the grass could be eaten by the cow; (2) an unperfect circle image as area that the grass could be eaten by the cow, a radius drawn as the cow rope, and a center of circle as a tree in the land; (3) an isosceles triangle image was the result of separation from unperfect circle image (2); (4) a right triangle image was the result of separation from isosceles triangle image (3). As explained at the aspect of formulating problem, SK poured what she understood into images when she faced a story problem, especially containing geometry material. This is in accordance with Soenarjadi (2020) that image representation plays an important role in solving geometry problems and will facilitate the problem solving. SK also represented the mathematics problem into symbols according to the concepts she chose. 


\section{Solve}

\section{Devising a Plan}

SK devised strategy in order able to find concepts that were relevant to the mathematics problem she faced. The strategy was observing and analyzing the combination image of some planes, which represented the whole problem situation, then breaking it into several parts. The strategy was chosen because SK said that it could make her easier to find formulas that were relevant to the problem. This is accordance with kinesthetic students explained by James (2009) that kinesthetic students will learn and easily absorb information by touching and doing. Then SK applied the strategy she devised to find the formulas. Firstly, SK observed and analyzed the combination image of some planes (1) she made (see Figure 8). Then, SK broke that image into several planes, namely unperfect circle, isosceles triangle, and right triangle. From what SK did, she found the formulas of Pythagorean, isosceles triangle area, sector area, trigonometric ratios, and addition to solve problem.

\section{Carrying Out The Plan}

SK solved the problem by using the formulas she found before until finding the appropriate final answer. The following is SK's problem solving.

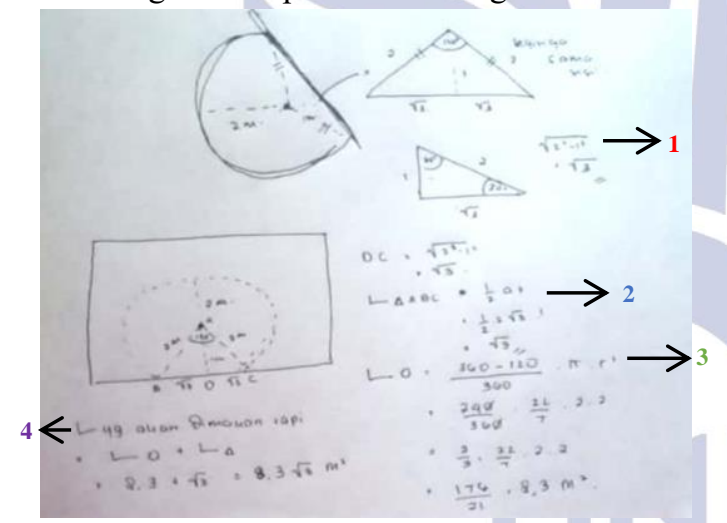

Figure 9. SK's Problem Solving

Based on Figure 9 and the interview with SK, firstly SK determined the length of right tringle base (1) by using the Pythagorean theorem. After that, she continued to determined the area of isosceles triangle (2). Then, SK determined the area of sector (3). For finding the area of sector, SK needed to determine the angle of the sector. She determined it by using the trigonometric ratios. The following is SK's calculation to find the angle of the sector during the interview section.

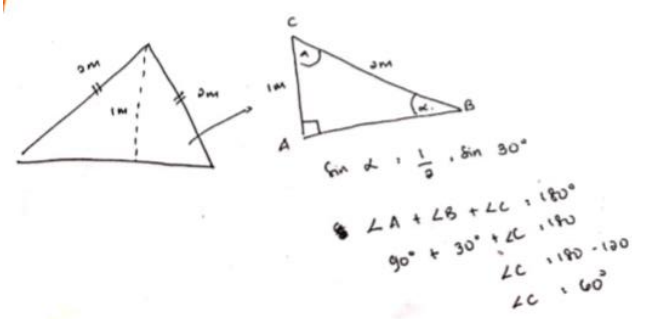

Figure 10. SK's Calculation

From Figure 10, SK used the trigonometric ratios to know the angle of $\angle C$ which was $60^{\circ}$. Hence, the angle of the sector obtained by,

$$
360^{\circ}-(2 \times m \angle C)=240^{\circ}
$$

After finding the area of the sector, SK determined the area of the land which the grass could be eaten by the cow (4) by adding the area of sector with the area of isosceles triangle.

Based on the interview with SK, she believed that there might be other ways to solve the mathematics problem she faced, but she was unable to find other ways.

\section{Looking Back}

SK realized that re-checking her answer sheet before being collected was necessary, but it depends on the situation and conditions. She said that the way she checked her answers was to check randomly to find something not appropriate and unsure. She would try to find its solution. If no solution was found, then she might check from the beginning again (understanding the problem). When SK re-checked her answer she only did it once. SK immediately found the error thing, it was in the image she made when pouring ideas from the process of understanding problem. After SK found out her mistake, she immediately sought a solution by reading the question again and starting to adjust all her works.

From the explanation above, we can see that at the aspect of formulating and solving problem (devising a plan step), SK often involved physical activities or movements. This is accordance with Pierce (2019) that kinesthetic students move a lot or involve a lot of physical movements during problem solving.

\section{CLOSURE}

\section{Conclusion}

Based on the results and discussion above, it can be concluded as follows.

\section{Visual Student's Strategic Competence Profile in} Solving Mathematics Problem

At the aspect of formulating problem, visual student understood the problem by reading carefully, silently, and repeatedly. Then, she imagined the problem situation and poured it into images. Visual student mentioned the known and unknown information verbally without looking at the text while pointing at the image she made.

At the aspect of representing problem, visual student used the images and symbols representations according to the concept she chose. 
At the aspect of solving problem, to find concepts and formulas that are relevant to the problem situation, visual student used the strategy of observing and analyzing images that were made in accordance with the problem then breaking the images into several parts. The concepts and formulas selected and used by visual student were the area of isosceles triangle, the area of semicircle, the area of two sectors, Pythagorean, trigonometry (the law of sine), and addition concept to solve problem. Visual student solved the problem according to the concepts and formulas she chose, but she could not solve problem in other different ways. Then, visual student realized that re-checking the problem solving obtained was necessary, but she did not re-check her answer sheet.

\section{Auditory Student's Strategic Competence Profile in} Solving Mathematics Problem

At the aspect of formulating problem, auditory student understood the problem by reading in a low voice and repeatedly. Then, she drew the problem situation. Auditory student mentioned the known and unknown information verbally and fluently without any help and in writing that appeared on her answer sheet.

At the aspect of representing problem, auditory student used the images and symbols representations according to the concept she chose.

At the aspect of solving problem, to find concepts and formulas that are relevant to the problem situation, auditory students used the strategy of observing images she made in accordance with the problem while remembering concepts that were relevant to the problem situation. The concepts and formulas chosen and used by auditory student were the area of circle, the area of sector, the area of scalene triangle, and subtraction concept to find the area of segment and the final solution of the problem. Auditory student solved the problem according to the concepts and formulas she chose, but she could not solve problem in other different ways. Then, auditory student realized that re-checking the problem solving obtained was necessary, but she did not re-check her answer sheet.

3. Kinesthetic Student's Strategic Competence Profile in Solving Mathematics Problem

At the aspect of formulating problem, kinesthetic student understood the problem by reading silently the words presented in the problem while pouring what she understood into images. Meanwhile, kinesthetic student mentioned the known and unknown information verbally without looking at the text and followed by her body cues.

At the aspect of representing problem, kinesthetic student used the images and symbols representations according to the concept she chose.

At the spect of solving problem, to find concepts and formulas that are relevant to the problem situation, kinesthetic student used the strategy of observing and analyzing images she made in accordance with the problem then breaking the images into several parts. The concepts and formulas selected and used by kinesthetic student were Pythagorean, the area of isosceles triangle, the area of sector, trigonometric ratios, and addition concept to solve problems. Kinesthetic student solved the problem according to the concepts and formulas she chose, but she could not solve problem in other different ways. Then, kinesthetic student realized that re-checking the problem solving obtained was necessary. Her strategy in re-checking was checking randomly to find something that was not appropriate and unsure for her. She would try to find solution to her discrepancies and uncertainties. If no solution was found, then she would check from the beginning again (understanding problem).

Based on the results and discussion, it can also be concluded that only kinesthetic student was able to solve the mathematics problem properly. Whereas visual and auditory student had the right answer but by coincidence. Visual student lacked understanding of the whole problem situation and could not connect some information which made her not being able to formulate the problem correctly. While auditory student, in the middle of the solution, was less able to analyze the situation so she could not determine the concept as a solution. Auditory student decided to guess the solution without being able to explain mathematically. At the aspect of solving problem, no one was able to solve the problem in another different way. This shows that students need to be facilitated in exploring various strategies for solving mathematics problems.

\section{Suggestion}

Students need to be familiarized and facilitated to explore various mathematics problem solving strategies. So that for mathematics teachers, it is expected to provide appropriate learning facilities for students by paying attention to various kinds characteristics of students. However this research still has many limitations and shortcomings, namely the data collection of this study was carried out with the help of online media caused by conditions that did not support to retrieve data directly. Therefore, for further researchers who will conduct research that is relevant to this study, it will be better to collect the data directly in order to reveal the profiles of students' strategic competence in greater depth and the results obtained more leverage.

\section{REFRENCES}


Aljaberi, Nahil M. 2015. "University Student's Learning Styles and Their Ability to Solve Mathematical Problems". International Journal of Business and Social Science. Vol. 6 (4): pp 152-165.

Bire, Arylien L., Geradus, Uda, dan Bire, Josua. 2014. "Pengaruh Gaya Belajar Visual, Auditorial, dan Kinestetik Terhadap Prestasi Belajar Siswa". Jurnal Kependidikan. Vol. 44 (2): pp168-174.

Deporter, Bobbi and Hernacki, Mike. 2004. Quantum Learning: Membiasakan Belajar Nyaman dan Menyenangkan. Translated by Alwiyah Abdurrahman. Bandung: Kaifa.

Gilakjani, Abbas P. 2012. "Visual, Auditory, Kinesthetic Learning Styles and Their Impacts on English Language Teaching". Journal of Studies in Education. Vol. 2 (1): pp 104-113.

Gunawan, Adi W. 2007. Genius Learning Strategy: Petunjuk Praktis untuk Menerapkan Accelerated Learning. Jakarta: PT Gramedia Pustaka Utama.

Hartati, Sulis J. 2012. Pemahaman Konsep Pembagian pada Siswa Sekolah Dasar Ditinjau dari Perbedaan Gaya Belajar. Unpublished dissertation. Surabaya: PPs Universitas Negeri Surabaya.

James, B. 2009. "What's Your Learning Style". Retrieved March.

Kilpatrick, Jeremy, Swafford, Jane, and Findell, Bradford. 2001. Adding It Up: Helping Children Learn Mathematics. Washington: National Academy Press.

Manullang, Sudianto, Kristianto, Andri, Hutapea, Andri T., Sinaga, lasker P., Sinaga, Bornok, Marianus, Mangaratua, dan Sinambela, Pardomuan N. J. M. 2017. Matematika SMA/MA/SMK/MAK Kelas XI. Second Edition. Jakarta: Kementerian Pendidikan dan Kebudayaan.

Ma'rifatin, Siti. 2018. Penalaran Spasial Siswa MTs dalam Menyelesaikan Soal Geometri Ditinjau dari Perbedaan Gaya Belajar. Unpublished thesis. Surabaya: PPs Universitas Negeri Surabaya.

Meilando, Reksy, Idris, Mustamin, dan Murdiana, I Nyoman. 2017. "Profil/Pemecahan Masalah Aritmatika Sosial Siswa Kelas VIII SMP Labschool UNTAD Palu Ditinjau dari Kemampuan Matematika”. Jurnal Elektronik Pendidikan Matematika Tadulako. Vol. 5 (2): pp 214-229.

Permendikbud. 2016. Salinan Lampiran Peraturan Menteri Pendidikan dan Kebudayaan Nomor 21 Tahun 2016 Tentang Standar Isi Pendidikan dan Menengah:
Standar Isi Pendidikan Dasar dan Menengah. Jakarta: Kemendikbud.

Pierce, Sara. 2019. "The Role of Gender and Learning Modality in Mathematical Problem Solving". Metamorphosis. Page 1-17.

Pusat Penilaian Pendidikan Kementerian Pendidikan dan Kebudayaan (Puspendik Kemendikbud). 2019. Laporan Hasil Ujian Nasional: Penguasaan Materi Ujian Nasional, (Online), (https://hasilun.puspendik.kemdikbud.go.id/\#2019!sm a!daya serap!99\&99\&999!a\&03\&T\&T\&1\&!1!\&.)

Samuelsson, Joakim. 2010. "The Impact of Teaching Approaches on Student's Mathematical Proficiency in Sweden". International Electronic Journal of Mathematics Education. Vol. 5 (2): pp 61-78.

Soenarjadi, Gatot. 2020. "Profil Pemecahan Masalah Siswa dalam Menyelesaikan Masalah Geometri Ditinjau dari Perbedaan Jenis Kelamin dan Gaya Belajar". Jurnal Riset Pendidikan dan Inovasi Pembelajaran Matematika (JRPIPM). Vol. 3 (2): pp 78-91.

Suh, Jennifer M. 2007. "Tying It All Together: Classroom Practices That Promote Mathematical Proficiency for All Students". Journal of Teaching Children Mathematics. Page 163-169.

Syukriani, Andi. 2016. "Kompetensi Strategis Siswa SMA Berkemampuan Matematika Tinggi dalam Menyelesaikan Masalah Matematika". Prosiding Seminar Nasional. Vol. 2 (1): pp 83-91.

Syukriani, Andi, Juniati, Dwi, and Siswono, Tatag Y. E. 2017. "Investigating Adaptive Reasoning and Strategic Competence: Difference Male and Female". AIP Conference Proceeding. Page 1-7.

Syukriani, Andi, Juniati, Dwi, and Siswono, Tatag Y. E. 2017. "Strategic Competence of Senior Secondary School Students in Solving Mathematics Problem Based on Cognitive Style". AIP Conference Proceeding. Page 1-6

Syukriani, Andi. 2018. Profil Penalaran Adaptif dan Kompetensi Strategis Siswa SMA dalam Menyelesaikan Masalah Matematika Berdasarkan Gaya Kognitif dan Gender. Unpublished dissertation. Surabaya: PPs Universitas Negeri Surabaya.

Wasida, Maria R. dan Hartono, H. 2018. "Analisis Kesulitan Menyelesaikan Soal Model Ujian Nasional Matematika dan Self-efficacy Siswa SMA”. Jurnal Riset Pendidikan Matematika. Vol. 5 (1): pp 82-95. 